Article

\title{
A Snap-Shot of Domatial Mite Diversity of Coffea arabica in Comparison to the Adjacent Umtamvuna Forest in South Africa
}

\author{
Sivuyisiwe Situngu ${ }^{1, *,+}$, Nigel P. Barker ${ }^{2}(\mathbb{D})$ and Susanne Vetter ${ }^{1}(\mathbb{D}$ \\ 1 Botany Department, Rhodes University, P.O. Box 94, Makhanda 6139, South Africa; S.Vetter@ru.ac.za \\ 2 Department of Plant and Soil Sciences, University of Pretoria, P. Bag X20, Hatfield 0028, South Africa; \\ nigel.barker@up.ac.za \\ * Correspondence: sivu.situngu@wits.ac.za; Tel.: +27-(0)11-767-6340 \\ + Present address: School of Animal, Plant and Environmental Sciences, University of Witwatersrand, \\ Private Bag 3, Johannesburg 2050, South Africa.
}

Received: 21 January 2020; Accepted: 14 February 2020; Published: 18 February 2020

\begin{abstract}
Some plant species possess structures known as leaf domatia, which house mites. The association between domatia-bearing plants and mites has been proposed to be mutualistic, and has been found to be important in species of economic value, such as grapes, cotton, avocado and coffee. This is because leaf domatia affect the distribution, diversity and abundance of predatory and mycophagous mites found on the leaf surface. As a result, plants are thought to benefit from increased defence against pathogens and small arthropod herbivores. This study assesses the relative diversity and composition of mites on an economically important plant host (Coffea aribica) in comparison to mites found in a neighbouring indigenous forest in South Africa. Our results showed that the coffee plantations were associated with only predatory mites, some of which are indigenous to South Africa. This indicates that coffee plantations are able to be successfully colonised by indigenous beneficial mites. We also found an "edge effect", in that coffee trees at the edge of the plantation hosted fewer mite species. These results are a snap-shot from a single sampling period. Nonetheless, they highlight the potential importance of this mutualism in commercial crop species and the possible role of faunal exchanges between indigenous and exotic crop species. This study expands our understanding of the mite-plant mutualism in Southern Africa, a region where acarological studies are sparse.
\end{abstract}

Keywords: leaf domatia-mite mutualism; Coffea arabica; mite diversity; edge effect; South Africa

\section{Introduction}

The commercial coffee plant, Coffea arabica L. (Rubiaceae), originates from Ethiopia and is cultivated worldwide in more than 50 countries [1,2]. Leaves of this species bear pit-type domatia, and coffee is one of many economically important species that have been shown to benefit from the association with mites [3-8]. Other economically important plants known to have an association with mites include grapes, avocado, sweet pepper plants and cassava [4,6,9-11]. The mutualism with mites is important in coffee because it may provide some relief from one of the most important diseases of coffee plants, the coffee leaf rust fungus (Hemilleia vastatrix Berk and Boome), and also from phytophagous mites [8]. In Brazil, the top coffee-producing country in the world, these benefits are appreciated, and more studies are being undertaken in an attempt to understand the possible interactions among the different mite species found in coffee and the favourable environmental conditions for the predaceous mites on coffee plants, in order to improve their integrated pest management programs for coffee agroforest systems [12]. Furthermore, coffee plants may also benefit from an increased overall fitness due to a decrease in the damage caused by plant enemies. Agrawal et al. [4] showed that cotton plants with 
artificial domatia added to them had increased populations of predatory mites and that their cotton yield was enhanced compared to plants without domatia.

In many countries that produce coffee, the coffee red mite, Oligonychus ilicis McGregor (Tetranychidae), is a common pest $[3,8,13,14]$. Even so, coffee leaves with healthy domatia have been shown to harbour more beneficial mites than pest mites $[11,12,15]$. In North Queensland, the majority of the mites found inside the domatia of coffee were primarily predatory from the families Stigmaeidae, Phytoseiidae and Bdellidae [3]. In Brazil, predatory mites such as Euseius citrifolius Denmark and Muma and Euseius concordis (Chant) are associated with coffee, and these mites control the pest mites Brevipalpus phoenicis (Geijskes) and Oligonychus ilicis [12]. Even though these mites are currently not listed as pest mites in South Africa, their related species such as Oligonychus coffeae (Nietner) and Oligonychus mangiferus (Rahman and Sapra) are known pests.

In South Africa, coffee is not widely cultivated, and according to an official government website, only approximately 200 ha are cultivated, with a national yield of 3500 bags (60 kg per bag; however, note that this information dates back to 2014). In comparison, Brazil, which is the top coffee-producing country, supplies nearly 48 million bags [16]. Perhaps for this reason, little is known about the mites that occupy the domatia of coffee grown in South Africa, and studies on the domatia-facilitated plant-mite mutualism in Africa as a whole are rare. Despite the importance of the mites in coffee, there is little information about the fauna of predatory mites found in these plants and about the influence that neighbouring vegetation exerts as a reservoir of predatory mites, even in Brazil.

The aim of this study was to examine the mite communities found inside the domatia of coffee plants in South Africa and to compare the mite fauna with that found in leaf domatia-bearing plant species in the adjacent indigenous forest, thereby contributing to the knowledge of mites associated with domatia, from both an exotic crop species and indigenous trees from an understudied region.

Based on the literature, we hypothesised that the coffee plantations would harbour beneficial mites inside their domatia and primarily predatory species which are similar to those found in the adjacent forest. We further hypothesised that the diversity of possible host plants in the forest would result in greater mite diversity in the forest, but that some of the mite taxa may have dispersed and established themselves in the coffee plantation.

\section{Materials and Methods}

Beaver Creek Coffee monoculture plantation in Port Edward, KwaZulu-Natal Province, South Africa, was selected as the study site ( $\left.31^{\circ} 02^{\prime} 40.86^{\prime \prime} \mathrm{S} ; 30^{\circ} 10^{\prime} 48.18^{\prime \prime} \mathrm{E}\right)$. The study was conducted in February of 2015, during the summer season in South Africa. We chose to sample during this season because our results from a previous study of the effects of seasonality on the distribution of mites suggested that mites inhabit domatia during all seasons and mite abundance was highest in summer and autumn [17]. The Beaver Creek Coffee plantation was selected due to its close proximity (about 200 metres) to the indigenous Umtamvuna Forest (Figure 1). From our observation, this forest was intact, with a well-developed canopy and understorey tree layers.

Four transects were randomly laid out across the plantation: two laid in the middle of the plantation and two at the edge of the plantation. These two transect lines for both the edge and the middle were laid next to each other, parallel to the plant rows. Both the edge of the plantation closest to the forest and in the middle of the plantation were sampled to test whether there would be higher abundance and a different suite of mites at the edge of the plantation compared to the middle. Twenty leaves were sampled from each of 10 individual coffee trees that were randomly selected along the transect line. When sampling, mature leaves with fully developed domatia were chosen from all around the tree. In addition to this, forest walks in the neighbouring Umtamvuna Forest were undertaken, and twenty leaves were sampled from each plant species found to possess leaf domatia. 
The leaves were placed in a reseal-able plastic bag and stored in a cooler box with ice, to keep the mites sessile. The mites were then viewed under a dissecting microscope, on the same day the sampling took place. Mites found inside domatia were counted before they were collected for identification. Mites were removed and collected from leaves using a pipette and a drop of alcohol, mounted on a slide using PVA mounting medium, and viewed under an Olympus light microscope. Some individuals were mounted on a stub, using a double-sided tape, coated with carbon, and viewed under a scanning electron microscope. Mite species abundance (average number of mites per leaf), composition and the Shannon diversity index for both sites were calculated.

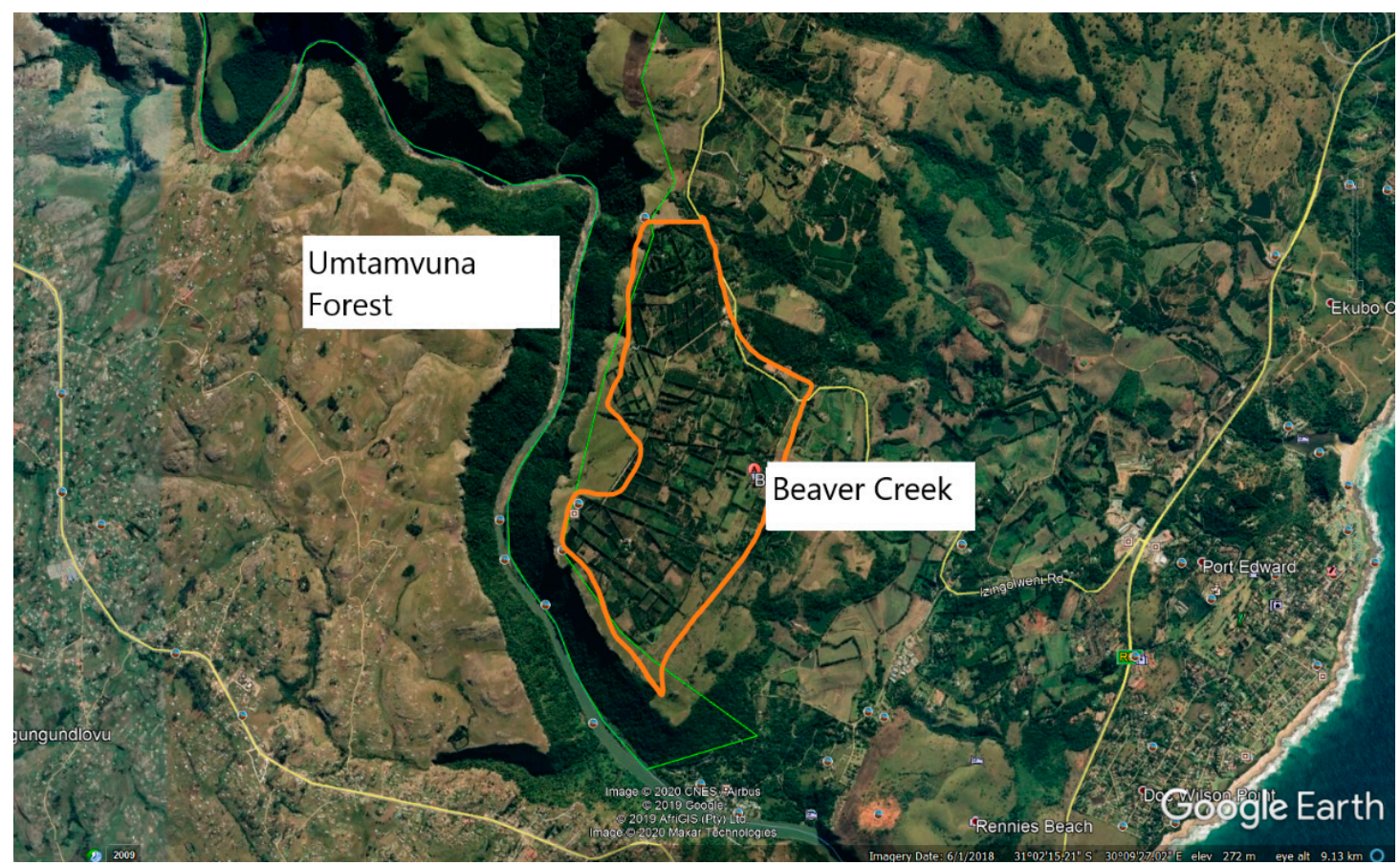

Figure 1. A Google Earth image showing the close proximity of Beaver Creek Coffee plantation to Umtamvuna forest. (Image (C) 2020 Maxar technologies).

A list of all mite species collected from each of the plant species from the different sampling sites was collated, and a presence-absence data matrix was produced, where " 1 " represented the presence of a species of mite in a sampled tree, and " 0 " its absence. Prior to analysis, the data were subjected to the "Absence and Presence" transformation option in PRIMER 6 software package, where each sampling unit was one plant (based on 20 leaves per plant). The presence-and-absence transformation allows for the less abundant mite species to have the same weighting as abundant ones.

A resemblance analysis (Bray-Curtis resemblance) using the software PRIMER 6 [18] was then performed. From this analysis, a dendrogram plot was produced, using the "group average" linkage to identify relationships and similarities in mite biota between the host species sampled. A similarity percentage analysis (SIMPER) was also conducted to determine which mite species are characteristic of the different vegetation types and to identify which mites contribute most to the similarity between vegetation types and within sample sites. 


\section{Results}

Twenty-seven different plant specimens from 18 species were sampled from Umtamvuna forest, and 40 plants (10 plants per transect; four transects) were sampled from a coffee plantation that is a monoculture. Table 1 lists all the mite species collected from the coffee plantation and the neighbouring Umtamvuna forest and also gives the total abundance and frequency for each of the mite species collected. In total, nine different species of mites were collected from leaves of coffee, and 20 mite species were found on the forest tree species. Furthermore, these results show that three mite species were exclusively found in coffee and 14 mite species were found exclusively in the forest (Table 1). The most abundant species in coffee were Euseus addoensis and Typhlodromus crassus (both predaceous). In the adjacent forest, the predacious mite Amblyseius anomalus and an herbivorous mite Eriophyid species were the most abundant.

The samples from the coffee plantation formed a distinct cluster in the multivariate analysis with the exception of three samples from the edge of the plantation that were grouped with Canthiun cilliatum (Figure 2), which is a shrub. However, there is no clear separation between the samples from the edge and the centre of the plantation. This shows that the coffee plantation had a different suite of mite species when compared to those found in the adjacent forest patch.

Similarly, where multiple trees of the same species were sampled from the indigenous forest (five species were sampled more than once), the mite fauna did not group the specimens of these species together, suggesting that the host selection of the mites in the forest is rather eclectic.

Tables 2 and 3 give the results of the similarity percentage analysis, within group similarity and between group dissimilarity, respectively, and the top three mite species that contributed to the similarity at the different sites. This analysis allows us to account for which species explain similarities and dissimilarities between the groups. The natural forest had a low percentage similarity value $(31.2 \%)$, and the coffee plantation had a slightly higher within group similarity value (middle 68.2\%; edge $46.2 \%$ ). The dissimilarity values when comparing different vegetation sites were high (Table 3 ). 
Table 1. A list of the mite species collected from the coffee plantation and the neighbouring Umtamvuna forest. Here, we have indicated the total abundance and frequency (i.e., the percentage number of samples in which each mite was found), for each of the sampled locations.

\begin{tabular}{|c|c|c|c|c|c|}
\hline Mite Species & Feeding Guild & $\begin{array}{l}\text { Coffee Edge: Abundance } \\
\text { (\% Frequency) }\end{array}$ & $\begin{array}{l}\text { Coffee Middle: } \\
\text { Abundance (\%) } \\
\text { Frequency) }\end{array}$ & $\begin{array}{c}\text { Natural Forest: } \\
\text { Abundance (\%) } \\
\text { Frequency) }\end{array}$ & $\begin{array}{l}\text { Total: Abundance } \\
\text { (\% Frequency) }\end{array}$ \\
\hline $\begin{array}{c}\text { Cheyletidae } \\
\text { Prosocheyla hepburni (Lawrence) }\end{array}$ & Predacious & & & $14(7 \%)$ & $14(3 \%)$ \\
\hline $\begin{array}{c}\text { Cunaxidae } \\
\text { Bunaxella quini Den Heyer } \\
\text { Rubroscirus sp. }\end{array}$ & $\begin{array}{l}\text { Predacious } \\
\text { Predacious }\end{array}$ & $15(25 \%)$ & $28(30 \%)$ & $\begin{array}{c}37(15 \%) \\
5(4 \%)\end{array}$ & $\begin{array}{c}80(24 \%) \\
5(1 \%)\end{array}$ \\
\hline $\begin{array}{l}\text { Eriophyidae } \\
\text { Eriophyid sp. }\end{array}$ & Herbivorous & & & $104(19 \%)$ & $104(7 \%)$ \\
\hline $\begin{array}{l}\text { Eupodidae } \\
\text { Eupodes sp. }\end{array}$ & Algiphagus & & & $17(15 \%)$ & $17(6 \%)$ \\
\hline $\begin{array}{l}\text { Oribatida } \\
\text { Oribatid mite }\end{array}$ & Mycophagous/Saprophytic & & $2(10 \%)$ & $30(30 \%)$ & $32(12 \%)$ \\
\hline $\begin{array}{c}\text { Phytoseiidae } \\
\text { Amblyseius anomalus van der Merwe } \\
\text { Euseius addoensis (van der Merwe and Ryke) } \\
\text { Ueckermannseius sp } 1 \\
\text { Ueckermannseius sp2 } \\
\text { Ueckermannseius munsteriensis van der Merwe } \\
\text { Typhlodromus microbullatus van der Merwe } \\
\text { Typhlodromus crassus van der Merwe }\end{array}$ & $\begin{array}{l}\text { Predacious } \\
\text { Predacious } \\
\text { Predacious } \\
\text { Predacious } \\
\text { Predacious } \\
\text { Predacious } \\
\text { Predacious }\end{array}$ & $\begin{array}{l}212(95 \%) \\
2(10 \%) \\
77(50 \%)\end{array}$ & $\begin{array}{l}136(30 \%) \\
59(25 \%) \\
35(35 \%) \\
78(85 \%)\end{array}$ & $\begin{array}{c}227(56 \%) \\
9(4 \%) \\
18(26 \%) \\
73(41 \%) \\
7(7 \%) \\
4(4 \%)\end{array}$ & $\begin{array}{c}227(22 \%) \\
357(38 \%) \\
59(7 \%) \\
20(13 \%) \\
73(16 \%) \\
7(3 \%) \\
35(10 \%) \\
159(41 \%)\end{array}$ \\
\hline $\begin{array}{c}\text { Stigmaeidae } \\
\text { Agistemus tranatalensis Meyer } \\
\text { Agistemus sp. (probably new) } \\
\text { Mullederia centrata (Meyer) }\end{array}$ & $\begin{array}{l}\text { Predacious } \\
\text { Predacious } \\
\text { Predacious }\end{array}$ & $2(5 \%)$ & $15(20 \%)$ & $5(4 \%)$ & $\begin{array}{c}5(1 \%) \\
15(6 \%) \\
2(1 \%)\end{array}$ \\
\hline $\begin{array}{c}\text { Tenuipalpidae } \\
\text { Brevipalpus sp. (probably new) }\end{array}$ & Herbivorous & & & $8(11 \%)$ & $8(4 \%)$ \\
\hline $\begin{array}{c}\text { Tetranychidae } \\
\text { Oligonychus sp. (probably new) } \\
\text { Tetranychus sp. } \\
\text { Tetranychus nymph } \\
\end{array}$ & $\begin{array}{l}\text { Herbivorous } \\
\text { Herbivorous } \\
\text { Herbivorous }\end{array}$ & & & $\begin{array}{c}6(4 \%) \\
33(25 \%) \\
83(25 \%)\end{array}$ & $\begin{array}{c}6(1 \%) \\
33(10 \%) \\
83(10 \%)\end{array}$ \\
\hline $\begin{array}{c}\text { Triophtydeidae } \\
\text { Tetratriophtydeus myacanthus Ueckermann }\end{array}$ & Predacious & & & $5(4 \%)$ & $45(1 \%)$ \\
\hline
\end{tabular}


Table 1. Cont.

\begin{tabular}{|c|c|c|c|}
\hline $\begin{array}{c}\text { Tydeidae } \\
\text { Tydeus munsteri Meyer and Ryke }\end{array}$ & Predacious & $46(48 \%)$ & $46(19 \%)$ \\
\hline $\begin{array}{l}\text { Winterschmidtiidae } \\
\text { Saproglyphus sp. }\end{array}$ & Mycophagous & $11(15 \%)$ & $11(6 \%)$ \\
\hline
\end{tabular}

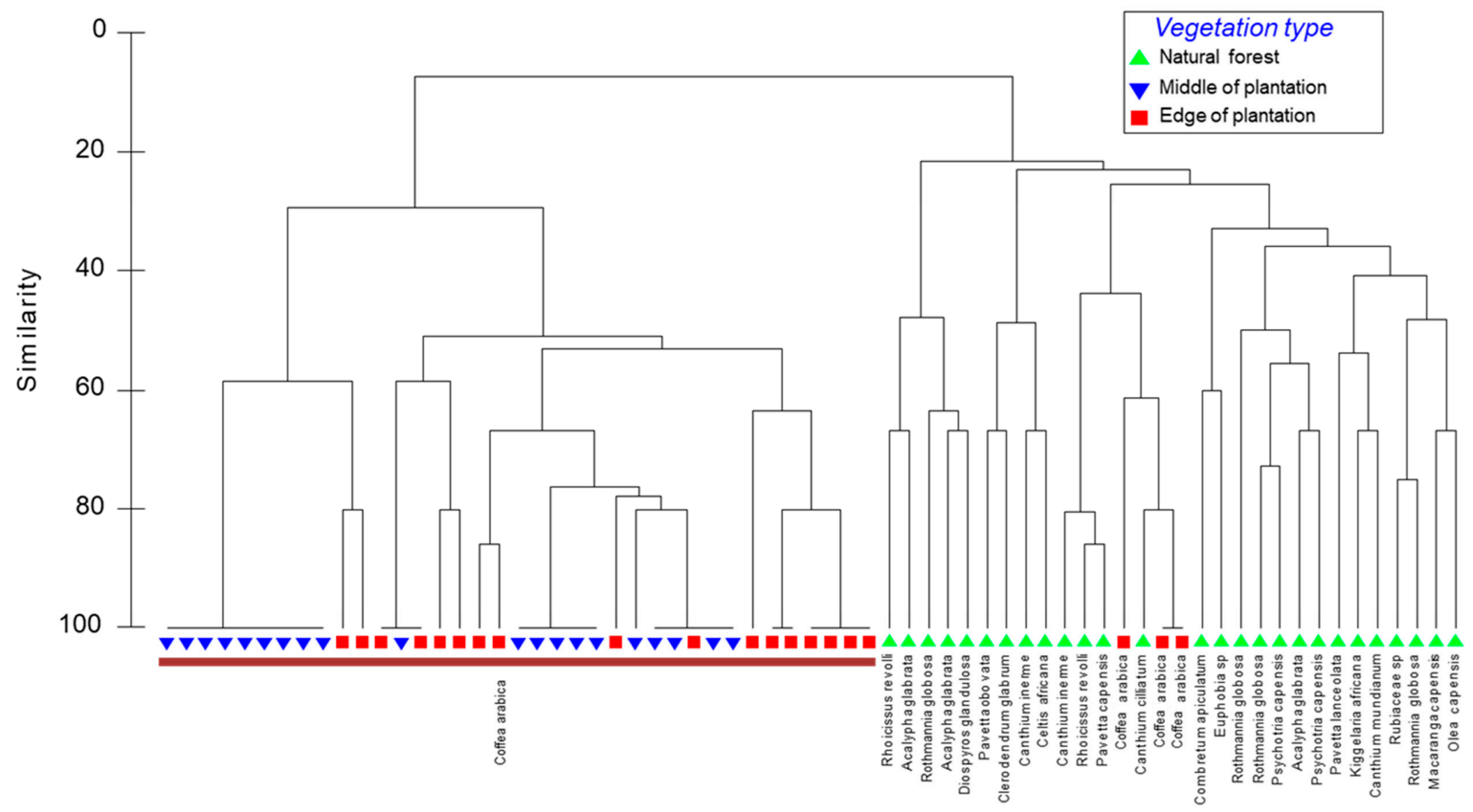

Figure 2. A group average dendrogram produced by using the Bray-Curtis similarity measure, showing similarities between coffee sample sites and the different indigenous plant species sampled from the adjacent forest. 
Table 2. The contribution of the mite species sampled to the average within group similarity amongst the sites sampled.

\begin{tabular}{|c|c|c|}
\hline Site & Average within Group Similarity (\%) & Contribution of Species (\%) \\
\hline Natural forest & 31.21 & $\begin{array}{c}\text { Phytoseiidae } \\
\text { Amblyseius anomalus (23.6) } \\
\text { Ueckermannseius munsteriensis (21.5) } \\
\text { Oribatida } \\
\text { Oribatid mite }(16.8)\end{array}$ \\
\hline $\begin{array}{c}\text { Middle of coffee } \\
\text { plantation }\end{array}$ & 68.27 & $\begin{array}{c}\text { Phytoseiidae } \\
\text { Euseius addoensis (81.1) } \\
\text { Typhlodromus crassus (16.0) }\end{array}$ \\
\hline $\begin{array}{l}\text { Edge of coffee } \\
\text { plantation }\end{array}$ & 46.17 & $\begin{array}{c}\text { Phytoseiidae } \\
\text { Typhlodromus crassus (70.2) } \\
\text { Cunaxidae } \\
\text { Bunaxella quini (8.7) } \\
\text { Phytoseiidae } \\
\text { Euseius addoensis (8.2) }\end{array}$ \\
\hline
\end{tabular}

Table 3. The contribution of the mite species sampled to the average dissimilarity between the sampled sites.

\begin{tabular}{|c|c|c|}
\hline Site & $\begin{array}{l}\text { Average between Group } \\
\text { Dissimilarity (\%) }\end{array}$ & Contribution of Species (\%) \\
\hline $\begin{array}{l}\text { Natural forest vs. middle of } \\
\text { plantation }\end{array}$ & 97.97 & $\begin{array}{c}\text { Phytoseiidae } \\
\text { Euseius addoensis (17.5) } \\
\text { Amblyseius anomalus (10.1) } \\
\text { Ueckermannseius Munsteriensis (9.7) }\end{array}$ \\
\hline $\begin{array}{l}\text { Middle of coffee plantation vs. } \\
\text { edge of plantation }\end{array}$ & 62.48 & $\begin{array}{c}\text { Phytoseiidae } \\
\text { Euseius addoensis (29.0) } \\
\text { Typhlodromus crassus (23.3) } \\
\text { Cunaxidae } \\
\text { Bunaxella quini (16.1) }\end{array}$ \\
\hline $\begin{array}{c}\text { Edge of coffee plantation vs. } \\
\text { natural forest }\end{array}$ & 89.64 & $\begin{array}{c}\text { Phytoseiidae } \\
\text { Typhlodromus crassus (15.0) } \\
\text { Amblyseius anomalus (9.9) } \\
\text { Phytoseius sp. }(9.4)\end{array}$ \\
\hline
\end{tabular}

The adjacent forest had a higher Shannon diversity index than the coffee plantation (Figure 3B), and when comparing the two sample sites within the coffee plantation, leaves collected in the middle of the plantation had more mites and a higher diversity index compared to samples collected at the edge (Figure 3A,B). 

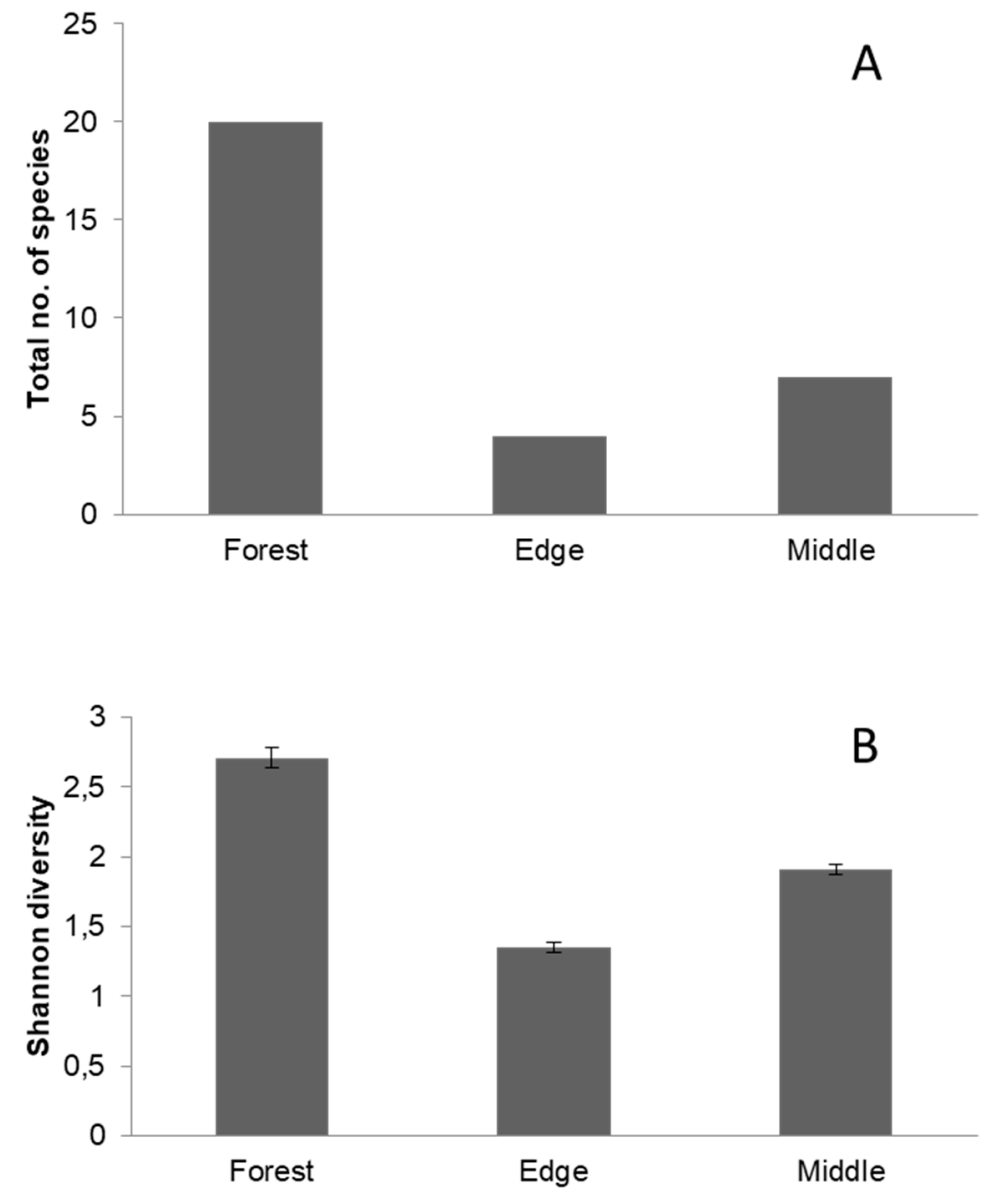

Figure 3. Shows (A) total number of mite species and (B) Shannon diversity index of mites collected from the Umtamvuna forest and two sites (middle and edge) in the Coffea arabica plantation.

\section{Discussion}

This study provides the first assessment of the mite biota found in coffee plants of South Africa. An improved understanding of mites found in coffee and how they assist in keeping the crop plant healthy is important. Our results from a single sampling period show that Coffee arabica is associated with more than one mite species occupying its domatia (Table 1). The coffee plantation had low mite species diversity when compared to the neighbouring indigenous forest (Figure 3B). The mites collected from the coffee plants belonged to the families Phytoseiidae, Stigmaeidae and Cunaxidae, and these are commonly found in leaf domatia all over the world. These are all predatory mites and mites from these families have previously been shown to be associated with coffee plantations [3,12]. Matos et al. [19] found that coffee domatia had a positive effect on the abundance of predatory mites, and plants with higher densities of domatia harbour more predatory mites and fewer prey mites. Mineiro at al. [20] and others [21] also found a higher number of predatory mites and phytophagous mites on coffee plants across different cropping systems. These results further support the hypothesis that domatia attract beneficial mites that act as the plant's "bodyguards" and highlight the importance of this mutualism in economically important species. In a study similar to ours, $\mathrm{O}^{\prime} \mathrm{Connell}$ et al. [22] found that native forests supported higher numbers of mite species than either plantation forest or pastoral grasses.

This beneficial mutualism has been shown in other commercial crop plants, including grapes, cassava and even cotton $[6,13,23,24]$. Avocado (Persea americana) plant leaves with domatia were found to be associated with more predatory mites and fewer herbivorous mites than those without domatia. Onzo et al. [6] showed that predatory mites help protect cassava plants by reducing herbivorous mites on young leaves, which are the most photosynthetically active and force herbivorous mite to move 
down the plant to less profitable older leaves. Norton et al. [5] found high densities of the beneficial mites Orthotydeus lambi on grape plants with intact domatia than on plants with blocked domatia. Both English-Loeb et al. [9] and Melidossian et al. [24] have shown that tydeid mite suppresses powdery mildew on the fruit and foliage of Vitis vinifera and that the mite could be an important bio-control agent for the grape powdery mildew, which is a pathogen of cultivated and wild grapes. Furthermore, grape vines with bigger domatia are resilient to pathogenic fungi because they support larger communities of fungivorous mites [23].

In our study, the mites found inside the domatia of coffee were all predatory. Other studies examining the occupants of coffee domatia also observed phytophagous mites such as Oligonychus ilicis and Brevipalpus phoenicis, which cause damage to the leaves $[8,19,25]$. However, we did not find any of these mites in our study site. This could be due to the fact that we only sampled the site once. Some potentially harmful mites were found in the Umtamvuna forest, but these appear not to have migrated to the plantation. Alternatively, these harmful mites could have been preyed upon by the predatory mites associated with the coffee plants. From this, we speculate that predatory mites which were found at the plantation were successful at keeping the plants healthy by preying on any harmful mite that landed on the coffee leaves. This is a widely accepted benefit that plants get as a result of producing domatia, and many studies $[5,12,15,23]$ support the hypothesis that mites act as plant "bodyguards" and protect plant leaves from their natural enemies.

When compared to the adjacent forest patch, coffee plants were found to possess a different suite of mites (Figure 2). These results were further supported by the SIMPER analysis, which gave higher dissimilarly values when comparing the two sampled sites (Tables 2 and 3). Three mite species (Mullederia centrata, Agistemus sp. (probably new) and Ueckermannseius sp1) were uniquely found in the coffee plantation and five species (Agistemus tranatalensis, Bunaxella quini, Euseius addoensis, Typhlodromus crassus and Ueckermannseius munsteriensis) were found in both the adjacent forest and in the coffee plantations (Table 1). These results suggest that, to some extent, certain mites had a preference for coffee plants over the species found in the adjacent forest patch. Some of these mites (Agistemus sp. (probably new). Ueckermannseius specis, Ueckermannseius munsteriensis, Euseius addoensis and Typhlodromus crassus, found on coffee plants, are indigenous to South Africa, suggesting that this exotic plant is not associated with its own mite that could have been imported from another country, and that indigenous mites are able to migrate and establish on exotic species. The origin of the three mite species found exclusively on the coffee plants (two of which are indigenous) is uncertain. Either they are present in the indigenous forest but were not sampled, or they were introduced along with the coffee plants, at the time the plantation was established. In a similar study assessing plant-inhabiting mite fauna associated with sugarcane, the important role that natural vegetation plays as a source of natural mites, which are enemies of pests, was demonstrated [26,27].

Interestingly, plants at the edge of the coffee plantation had fewer mites and a lower Shannon diversity compared to plants in the middle of the plantation (Figure 3B). This suggests that mites found on plants at the edge may be subjected to negative edge effects, as they were closest to the fire break path around the plantation, which is constantly mowed. An edge effect results when both biotic and abiotic conditions change along the boundary between two habitats, affecting the distribution, biodiversity and ecosystem functionality of species in both habitats [27,28]. A negative edge effect results when species found the edge of the habitat patch are exposed to an increased risk of parasitism, disease, increased predation, adverse microclimate conditions and increased competition from invasive species [27,29].

We suspect that this was also the case in this study and that this was due to the fact that the mites at the edge of the plantation would have been exposed to harsher environmental conditions, such as strong winds, exposure to rainfall and sunlight, as well as low relative humidity. Many species have been shown to suffer from edge effects [27,29-31], and in terms of arthropods, Lacasella et al. [32] showed that grassland species of spiders, centipedes and ground beetles were affected by the edge and this influence was evident up to $15 \mathrm{~m}$ from the habitat edge. Mites are delicate and are susceptible to these extreme conditions and thus avoid such habitats. Forest microclimate (patterns of temperature, moisture, 
wind and light) plays an important role in influencing insects and arthropod habitat selections $[33,34]$. Furthermore, relative humidity and exposure to sunlight have been shown to affect the distribution and diversity of mites within the tree canopy [35]. Croft et al. [36] showed that eggs and larvae of phytoseiid mites were sensitive to relative humidity and for all four species of phytoseiid mites subjected to humidity assays, egg and larvae mortality increased with decreasing humidity. To the best of our knowledge, this study is the first to show the impact of edge effects in mites.

\section{Conclusions}

Our results are from a single sampling period and do not show seasonal patterns of mite diversity. Even so, they indicate that, despite being adjacent to the indigenous forest, the coffee plantations at Beaver Creek were associated with a different suite of native species of predatory mites. This suggests that the coffee plantations are able to be successfully colonised by beneficial indigenous mites, but that migration of mite species between indigenous hosts and exotic crop species is limited. In addition, the coffee trees at the edge of the plantation were found to possess a lower diversity and slightly different suite of mites when compared to the plants from the middle of the plantation. These results highlight the importance of the mutualism between leaf domatia and mites in both commercial plants and indigenous species. This is important, as it implies that indigenous mites be effective at controlling pests on exotic crop species as an alternative to chemical control. Future studies that sample multiples times during the year and that compare mites found on leaves, branches and fruits will provide us with a better understanding of the diversity of mites found in coffee and the role of predatory mites in keeping plants healthy.

Author Contributions: Conceptualization, S.S. and N.P.B.; methodology, S.S.; formal analysis, S.S.; writingoriginal draft preparation, S.S.; review and editing, N.P.B. and S.V.; funding acquisition, N.P.B. and S.S. All authors have read and agreed to the published version of the manuscript.

Funding: This research was funded by the National Research Foundation (NRF) of South Africa and the Department of Science and Technology/National Research Foundation Centre of Excellence in Tree Health Biotechnology (CTHB) Grant UID 40943. The first author also acknowledges financial support from the Canon Collins Trust and GreenMatter.

Acknowledgments: We would like to thank Robby Cumming and Beaver Creek Coffee Estate for allowing us the opportunity to conduct sampling on their property. The assistance of friends and colleagues in the field is also gratefully acknowledged. Edward Ueckermann (Agricultural Research Council of South Africa, Biosystematics Division) is thanked for his assistance with mite identification.

Conflicts of Interest: The authors declare no conflicts of interest.

\section{References}

1. Vega, F.E.; Rosenquist, E.; Collins, W. Global project needed to tackle coffee crisis. Nature 2003, 425, 343. [CrossRef] [PubMed]

2. Vega, F.E.; Ochoa, R.; Astorga, C.; Walter, D.E. Mites (Arachnida: Acari) inhabiting coffee domatia: A short review and recent findings from Costa Rica. Int. J. Acarol. 2007, 33, 291-295. [CrossRef]

3. O'Dowd, D.J. Mite association with the leaf domatia of coffee (Coffea arabica) in North Queensland, Australia. Bull. Ent. Res. 1994, 84, 361-366. [CrossRef]

4. Agrawal, A. Do leaf domatia mediate a plant-mite mutualism? An experimental test of the effects on predators and herbivores. Ecol. Entomol. 1997, 22, 371-376. [CrossRef]

5. Norton, A.P.; English-Loeb, G.; Gadoury, D.; Seem, R.C. Mycophagous mites and foliar pathogens: Leaf domatia mediate tritrophic interactions in grapes. Ecology 2000, 81, 490-499. [CrossRef]

6. Onzo, A.; Hanna, R.; Zannou, I.; Sabelis, M.W.; Yaninek, J.S. Dynamics of refuge use: Diurnal, vertical migration by predatory and herbivorous mites within cassava plants. Oikos 2003, 101, 59-69. [CrossRef]

7. Vega, F.E.; Infante, F.; Castillo, A.; Jaramillo, J. The coffee berry borer, Hypothenemus hampei (Ferrari) (Coleoptera: Curculionidae): A short review, with recent findings and future research directions. Terr. Arthrop. Rev. 2009, 2, 129-147. 
8. Oliveira, C.M.; Ferreira, J.A.M.; Olivereira, R.M.; Santo, F.O.; Pallini, A. Ricoseius loxocheles, a phytoseiid mite that feeds on coffee leaf rust. Exp. Appl. Acarol. 2014, 64, 223-233. [CrossRef]

9. English-loeb, G.; Norton, A.P.; Gadoury, D.M.; Seem, R.C.; Wilcox, W.F. Control of Powdery Mildew in Wild and Cultivated Grapes by a Tydeid Mite. Bio. Con. 1999, 14, 97-103. [CrossRef]

10. Ferreira, J.A.M.; Eshuis, B.; Janssen, A.; Sabelis, M.W. Domatia reduce larval cannibalism in predatory mites. Ecol. Entomol. 2008, 33, 374-379. [CrossRef]

11. Ferreira, J.A.M.; Cunha, D.F.S.; Pallini, A.; Sabelis, M.W.; Janssen, A. Leaf domatia reduce intraguild predation among predatory mites. Ecol. Entomol. 2011, 36, 435-441. [CrossRef]

12. Mineiro, J.L.D.; Sato, M.E.; Raga, A.; Arthur, V. Population dynamics of phytophagous and predaceous mites on coffee in Brazil, with emphasis on Brevipalpus phoenicis (Acari: Tenuipalpidae). Exp. Appl. Acarol. 2008, 44, 277-291. [CrossRef]

13. Fahl, J.I.; Queiroz-Voltan, R.B.; Carrelli, M.L.C.; Schiavinato, M.A.; Pradro, A.K.S.; Souza, J.C. Alterations in leaf anatomy and physiology caused by the red mite (Oligonychus ilicis) in plants of Coffea arabica. Bra. J. Pl. Physiol. 2007, 19, 61-86. [CrossRef]

14. Romero, G.Q.; Daud, R.D.; Salomão, A.T.; Martins, L.F.; Feres, R.J.F.; Benson, W.W. Mites and leaf domatia: No evidence of mutualism in Coffea arabica plants. Bio. Neo. 2011, 11, 27-33. [CrossRef]

15. Pemberton, R.W.; Turner, C.E. Occurrence of predatory and fungivorous mites in leaf domatia. Amer. J. Bot. 1989, 76, 105-112. [CrossRef]

16. Agricultural Reseach Council. Available online: http://www.arc.agric.za/arc-itsc/Pages/Coffee-Information. aspx (accessed on 20 November 2019).

17. Situngu, S. An Investigation of the Leaf Domatia-Mite Mutualism in South Africa: Insights from Ecological Studies. Ph.D. Thesis, Rhodes University, Grahamstown, South Africa, 2017.

18. Clarke, K.R.; Gorley, R.N. PRIMER v6: User Manual/Tutorial; PRIMER-E: Plymouth, UK, 2006.

19. Matos, C.H.C.; Pallini, A.; Chaves, F.F.; Schoereder, J.S.; Janssen, A. Do domatia mediate mutualistic interactions between coffee plants and predatory mites? Ent. Exp. Et. App. 2006, 118, 185-192. [CrossRef]

20. Mineiro, J.L.C.; Sato, M.E.; Berton, J.H.C.; Raga, A. Mites (Arachnida: Acari) on coffee plants in forest fragment and conventional plantation in Monte Alegre do Sul, Atate of São Paulo, Brazil. Divulgação Scientífica 2019, 81, 1-30.

21. Agrawel, A.A.; Karban, R.; Colfer, R.G. How leaf domatia and induced plant resistance affect herbivores, natural enemies and plant performance. Oikos 2000, 89, 70-80. [CrossRef]

22. O'Connell, D.M.; Lee, W.G.; Monks, A.; Dickinson, K.J.M. Does microhabitat structure affect foliar mite assemblages? Ecol. Entomol. 2010, 35, 317-328. [CrossRef]

23. English-Loeb, G.; Norton, A.; Walker, M.A. Behavioral and population consequences of acarodomatia in grapes on phytoseiid mites (Acari: Mesostigmata) and implications for plant breeding. Ent. Exp. Et. Appl. 2002, 104, 307-319. [CrossRef]

24. Melidossian, H.S.; Seem, R.C.; English-Loeb, G.; Wilcox, W.F.; Gadoury, D.M. Suppression of grapevine powdery mildew by a mycophagous mite. Plant Dis. 2005, 89, 1331-1338. [CrossRef] [PubMed]

25. Chagas, C.M.; Kitajima, E.W.; Rodrigues, J.C.V. Coffee ringspot virus vectored by Brevipalpus phoenicis (Acari: Tenuipalpidae) in coffee. Exp. Appl. Acarol. 2003, 30, 203-213. [CrossRef] [PubMed]

26. Duarte, M.E.; Navia, D.; dos Santos, L.R.; Rideiqui, P.J.S.; Silva, E.S. Mites associated with sugarcane crop and with nativetrees from adjacent Atlantic forest fragment in Brazil. Exp. Appl. Acarol. 2015, 66, 529-540. [CrossRef] [PubMed]

27. Demite, P.R.; Feres, R.J.F.; Lofego, A.C. Influence of agricultural environment on the plant mite community in forest fragments. Braz. J. Biol. 2015, 75, 396-404. [CrossRef] [PubMed]

28. Murcia, C. Edge effects in fragmented forests: Implications for conservation. Trends Ecol. Evol. 1995, 10, 58-62. [CrossRef]

29. Harper, K.A.; Macdonald, S.E.; Burton, P.J.; Chen, J.; Brosofske, K.D.; Saunders, S.C.; Euskirchen, E.S.; Roberts, D.; Jaiteh, M.S.; Esseen, P. Edge influence on forest structure and composition in fragmented landscapes. Con. Biol. 2005, 19, 768-782. [CrossRef]

30. Ries, L.; Sisk, T.D. A predictive model of edge effects. Ecology 2004, 85, 2917-2926. [CrossRef]

31. Tian, C.; Yang, X.; Liu, Y. Edge effect and its impacts on forest ecosystem: A review. Chin. J. Appl. Ecol. 2011, 22, 2184-2192. 
32. Lacasella, F.; Gratton, C.; Felici, S.D.; Sbordoni, V. Asymmetrical responses of forest and "beyond edge" arthropod communities across a forest-grassland ecotone. Bio. Con. 2015, 24, 447-465. [CrossRef]

33. Chen, J.; Saunders, S.C.; Crow, T.R.; Naiman, R.J.; Brosofske, K.D.; Mroz, G.D.; Brookshire, L.; Franklin, J.F. Microclimate in Forest Ecosystem and Landscape Ecology: Variations in local climate can be used to monitor and compare the effects of different management regimes. BioScience 1999, 49, 288-297. [CrossRef]

34. Fukui, A. Indirect interactions mediated by leaf shelters in animal-plant communities. Pop. Ecol. 2001, 43, 31-40. [CrossRef]

35. Situngu, S.; Barker, N.P. Position, position, position: Mites occupying leaf domatia are not uniformly distributed in the tree canopy. SA J. Bot. 2016, 108, 23-28. [CrossRef]

36. Croft, B.A.; Messing, R.H.; Dunley, J.E.; Strong, W.B. Effects of humidity on eggs and immatures of Neoseiulus fallacis, Amblyseieus andersoni, Metaseiulus occidentalis and Typhlodromus pyri (Phytoseiidae): Implications for biological control on apple, caneberry, strawberry and hop. Exp. App. Acarol. 1993, 17, 451-459. [CrossRef]

(C) 2020 by the authors. Licensee MDPI, Basel, Switzerland. This article is an open access article distributed under the terms and conditions of the Creative Commons Attribution (CC BY) license (http://creativecommons.org/licenses/by/4.0/). 